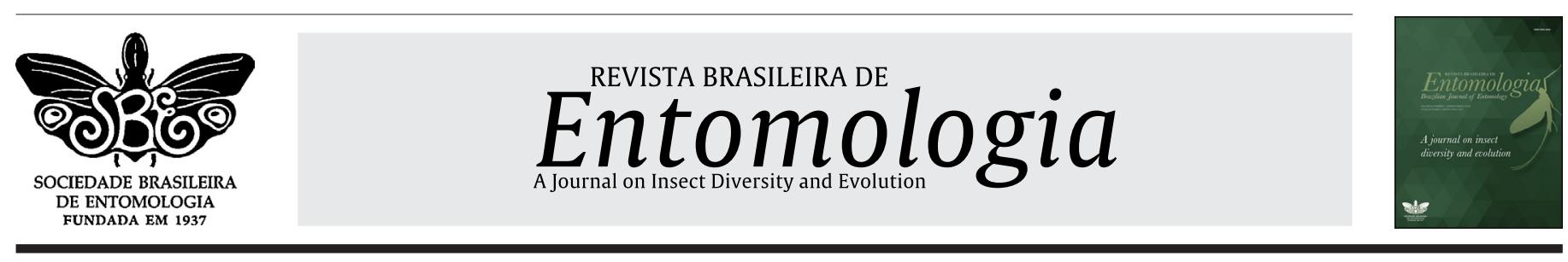

\title{
Identification and description of the antennal sensilla of Liogenys suturalis (Coleoptera: Scarabaeidae)
}

\author{
Flavio T. Menis ${ }^{1^{*}}$ (D), Juares Fuhrmann ${ }^{2}$ (D), Sérgio R. Rodrigues ${ }^{1}$ (D) \\ ${ }^{1}$ Universidade Estadual de Mato Grosso do Sul, Cassilândia, MS, Brasil. \\ ${ }^{2}$ Universidade de São Paulo, Museu de Zoologia, São Paulo, SP, Brasil.
}

\section{A R T I C L E I N F O}

\section{Article history:}

Received 30 April 2021

Accepted 27 July 2021

Available online 23 August 2021

Associate Editor: Adriana Marvaldi

\section{Keywords:}

Chemical communication

Pest

Chemoreceptors

Scarabaeoidea

Ultrastructure

\begin{abstract}
A B S T R A C T
Species of the scarab beetle genus Liogenys are potential pests to several crops in Brazil. This study aimed to describe the antennal sensilla of Liogenys suturalis (Blanchard, 1851). Adults were collected in a pasture area in Bálsamo, São Paulo state, Brazil, using a light trap. The antennae were dissected and images of the antennal sensilla were obtained using a scanning electron microscope. Sensilla ampulacea (pores), s. auricilica, s. basiconica, s. placodea, and s. trichodea are present in the lamellae. The antenna of females have 4399 sensilla, of which 3671 (83.5\%) are s. placodea, 422 (9.5\%) s. coeloconica, and 306 (6.9\%) s. auricilica. The antennae of males have 4039 sensilla, of which 3117 (77.1\%) are s. placodea, 353 (8.7\%) s. coeloconica, and 569 (14.1\%) s. auricilica. The antennal sensilla of the genus Liogenys have been described for the first time.
\end{abstract}

\section{Introduction}

The genus Liogenys Guérin-Méneville, 1831 (Coleoptera: Scarabaeidae: Melolonthinae: Diplotaxini) is registered from Panama to southern Argentina and Chile, and it includes 92 described species (Cherman et al., 2019, 2020, 2021). The occurrence of Liogenys species were reported in agricultural areas of Brazil causing damage to cultivated plants. Liogenys suturalis (Blanchard, 1851) was listed as a pest in corn (Zea mays L., Poaceae), oat (Avena byzantina C. Kock, Poaceae), and wheat (Triticum aestivum L., Poaceae) (Santos and Ávila, 2007, 2009; Santos et al., 2008).

Larvae of some species of Liogenys feed on root of some cultivated plants. Immatures of L. fusca Blanchard, 1851 and L. bidenticeps Moser, 1919 were found in crop succession systems with soybean (Glycine max (L) Merrill, Fabaceae), corn, and cotton (Gossypium hirsutum L., Malvaceae) (Rodrigues et al., 2011), larvae of L. fusca were also found in crops of sugarcane (Saccharum officinarum L., Poaceae) (Coutinho et al., 2011), and those of L. bidenticeps, L. obesa Burmeister, 1855, and L. sinuaticeps Moser, 1918 were reported in winter grains (Cherman et al., 2011). Larvae from these species cause damage to plants roots and chemicals have been used to their control (Santos et al., 2008; Ávila et al., 2014).

\footnotetext{
* Corresponding author.

E-mail: flavioterradas@gmail.com (F.T. Menis).
}

Adults of Liogenys carry out flights in the field between September and December when females lay their eggs, and the biological cycle lasts one year (Santos and Ávila, 2007; Rodrigues et al., 2008; Rodrigues et al., 2014a). Adults use leaves or flowers for their nutrition during the swarm. Adults of $L$. fusca were observed feeding on leaves and flowers of plants of the family Anacardiaceae, such as Anacardium occidentale L., Astronium fraxinifolium Schott, Myracrodruon urundeuva Allem., and Schinus terebinthifolius Raddi (Rodrigues et al., 2017). Adults of L. suturalisfeed on leaves of Schinus terebinthifolius (Ferreira et al., 2018) and those of $L$. bidenticeps feed on leaves of Schinus terebinthifolius and flowers of Anacardium occidentale (Rodrigues et al., 2017).

Studies have shown that adults of Scarabaeidae use different plant species as sources of food and they use this sites for mating (e.g., Maia and Schlindwein, 2006; Maia et al., 2013; Martínez et al., 2013; Rodrigues et al., 2014b, 2017). The adult aggregation is intermediated by the detection of valatines by the antennae of these insects (Leal, 1995, 1998).

Sensilla present in the antennae of adults of Scarabaeidae are responsible for detecting various stimuli linked to their behavior, such as detection of host plants, sexual pheromone, and oviposition sites, among other functions (e.g., Schneider, 1964; Leal and Mochizuki, 1993; Romero-López et al., 2004, 2010; Li et al., 2015; Rodrigues et al., 2019). 
Studies have been carried out to describe antennal sensilla for some groups of Scarabaeidae pests. Sensilla auricilica, s. basiconica, s. chaetica, s. coeloconica, s. placodea, and s. trichodea have been described in antennae of Anomala Samouelle (1819), Phyllophaga Herris (1827), and Popillia Serville (1825) (Leal and Mochizuki, 1993; Kim and Leal, 2000; Ochieng et al., 2002; Romero-López et al., 2004, 2010; Rodrigues et al., 2019). However, there is no information about the antennal sensilla of Liogenys. This study aimed to identify and describe the sensilla of the antennal club of L. suturalis, expanding the information about this potential pest.

\section{Material and methods}

Adults of Liogenys suturalis were collected from September to December 2018, using a Luiz de Queiroz light trap (Silveira Neto and Silveira, 1969) installed between an area cultivated with grass (Urochloa brizantha), rubber tree (Hevea brasiliensis), and vegetation of native Cerrado forest in Bálsamo municipality, São Paulo state (SP), Brazil.

The collected adults were taken to the laboratory of entomology at the Universidade Estadual do Mato Grosso do Sul, Cassilândia municipality, Mato Grosso do Sul state(MS), Brazil. They were separated by sex, following the descriptions presented by Santos and Ávila (2009). The lamellae of the antennal club of four males ( $n=4)$ and four females $(n=4)$ were dissected using a Motic stereoscopic microscope and stored in $20 \mathrm{~mL}$ glass flasks containing $70 \%$ alcohol. The lamellae were maintained in $80 \%$ alcohol for 10 minutes, $90 \%$ alcohol for 15 minutes, and 100\% alcohol for 20 minutes for cleaning (Tanaka et al., 2006; Romero-López et al., 2013).

The lamellae were dried to a critical point using a Leica ${ }^{\circledR}$ CPD300 dryer at the Universidade Estadual Paulista (UNESP), Ilha Solteira campus, SP. Subsequently, they were coated with gold using a Quorum ${ }^{\circledR}$ Q150T E turbo molecular pump. Images were obtained using a Zeiss ${ }^{\circledR}$ EVO LS15 scanning electron microscope (SEM), following the methodology adapted from Romero-López et al. (2013).

The images obtained in SEM were subjected to image enhancement filters available in the software Image-Pro Plus 6.0. The sensillae were quantified in the images obtained by SEM.

Sensilla terminology follows Keil (1999). Meinecke (1975) and Bohacz et al. (2020) were used as alternative sensilla terminologies (in brackets) to easily term comparison.

\section{Results}

In the experimental area, 118 adults of $L$. suturalis were collected, of wich 39 were collected in September, 71 in October, and 8 in November 2018. The antennae of $L$. suturalis have some barded long sensilla trichodea distributed in outer side of proximal lamella (Figure 1), in edges of medial lamella (Figure 2), and in anterior area of outer side of distal lamella (Figure 3).

Sensilla auricilica, s. coeloconica, s. placodea, and some pores (s. ampullacea, Figure 2F) are present on the inner and outer sides of the lamellae, except on outer side of proximal lamella (Figures 1-3).

All s. placodea are longitudinally long and narrow (Meinecke, 1975: sensilla J4; Bohacz et al., 2020: ES; Figures 2E, F and 3E). Sensilla placodea type I have an irregular and slightly wavy shape, smooth surface, have peripherical ditch, an average length of $31.51 \pm 1.49 \mathrm{m \mu}$ (19.31-45.00), and an average width of $5.33 \pm 0.36 \mathrm{m \mu}(3.13-10.63)$. Sensilla placodea type II have a smooth surface, an average length of $41.56 \pm 1.49 \mathrm{m \mu}$ (29.65-58.60), an average width of $1.60 \pm 0.06 \mathrm{m \mu}(1.38-2.06)$, and the peripherical ditch is indistinct.
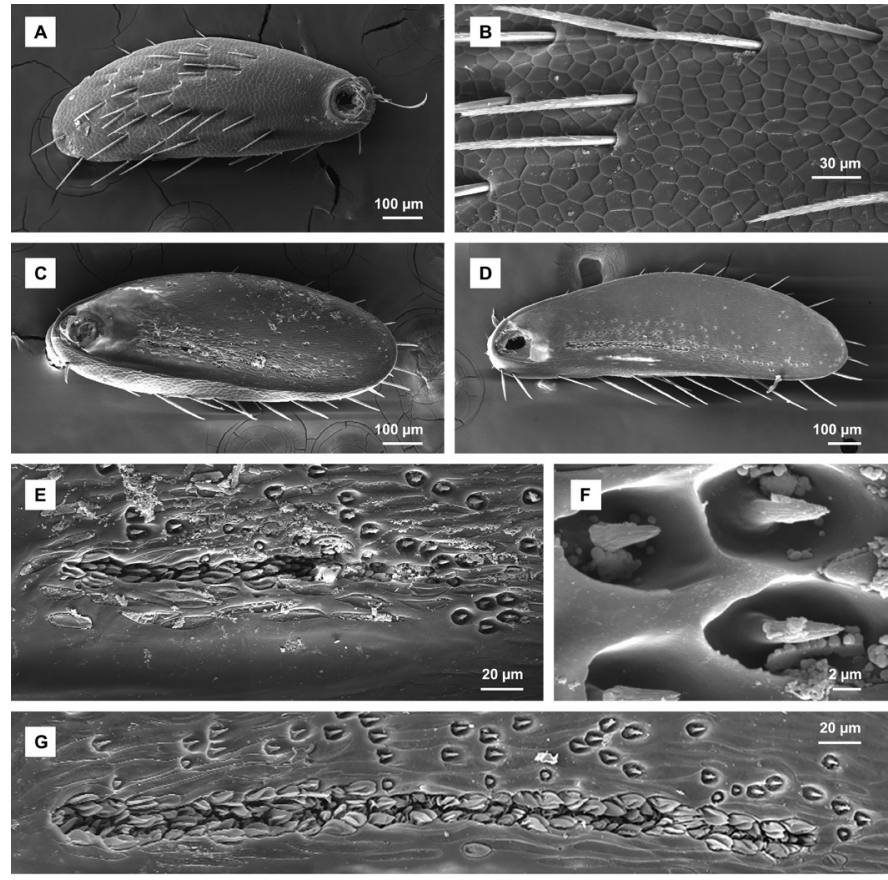

Figure 1 Proximal lamella of Liogenys suturalis. A) Outer (proximal) side, female. B) Outer side, detail of sensilla trichodea, female; C) Inner (distal) side, female. D) Inner (distal) side, male. E) Inner side, groove detail, female. F) Inner side, detail of sensilla coeloconica I, female. G) Inner side, groove detail with several sensilla auricilica, male.
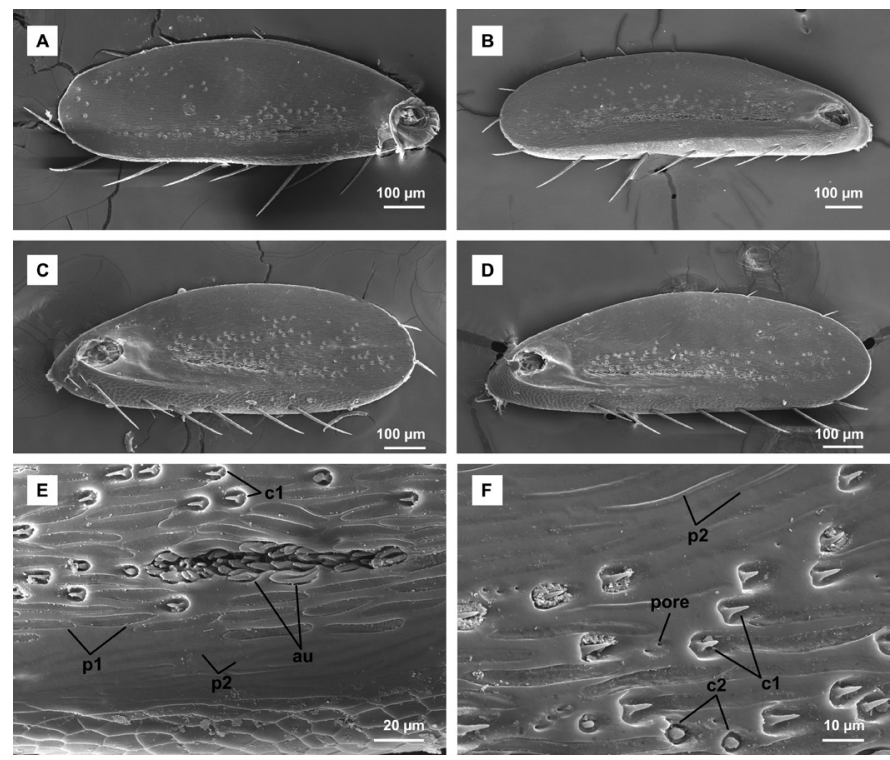

Figure 2 Medial lamella of Liogenys suturalis. A-B) Inner (proximal) side, female (rigth) and male (left). C-D) Outer (distal) side, female (rigth) and male (left). E) Inner side, groove detail, female. F) Outer side, sensilla detail, male. au, sensilla auricilica; c1, s. coeloconica I; c2, s. coeloconica II; p1, s. placodea I; p2, s. placodea II.

The antennae have sensilla coeloconica types I and II (Meinecke, 1975: sensilla J; Figures 2F and 3F). Type I are broad at the base and thin at the apex, and have some longitudinal grooves or striae ( Bohacz et al., 2020: sensilla GSC; Figures 1F, 2F and 3F), and type II are broad at the base with acute apex, and have smooth surface ( Bohacz et al., 2020: sensilla SC; Figures 2F and 3F).

Sensilla auricilica have shape variable and are flat, usually leafshaped, with a blunt, pointed, or forked tip (Bohacz et al., 2020: sensilla LSS). These sensilla are present mainly in longitudinal grooves present in inner side of proximal lamella (Figs. 1C-E, 1G), inner and outer 
sides of medial lamella (Figure 2A-E), and inner side of distal lamella (Figure 3A-B); otherwise s. auricilica are also present outward of the grooves, as in outer side of distal lamella (Figure $3 \mathrm{E}$ ). The length of the grooves are about three times longer in males (Figures 1D, G and 2B, D, B) than in females (Figures 1C, E, 2A, C and 2E, A).

Females have 4399 antennal sensilla, of which 3671 (83.5\%) are s. placodea, 422 (9.5\%) are s. coeloconica, and 306 (6.9\%) are s. auricilica. Males have 4039 antennal sensilla, of which 3117 (77.1\%) are s. placodea, $353(8.7 \%)$ are s. coeloconica, and 569 (14.1\%) are s. auricilica (Table 1 ).

Sensilla placodea type I occur at higher amounts in the central portion of the lamellae, while those of type II occur in the peripheral areas. Sensilla coeloconica and auricilica occur at higher amounts in the central portion of the lamellae.

\section{Discussion}

Correlation between morphology and function of antennal sensilla is difficult and some times links are carried out using some speculative assumptions.
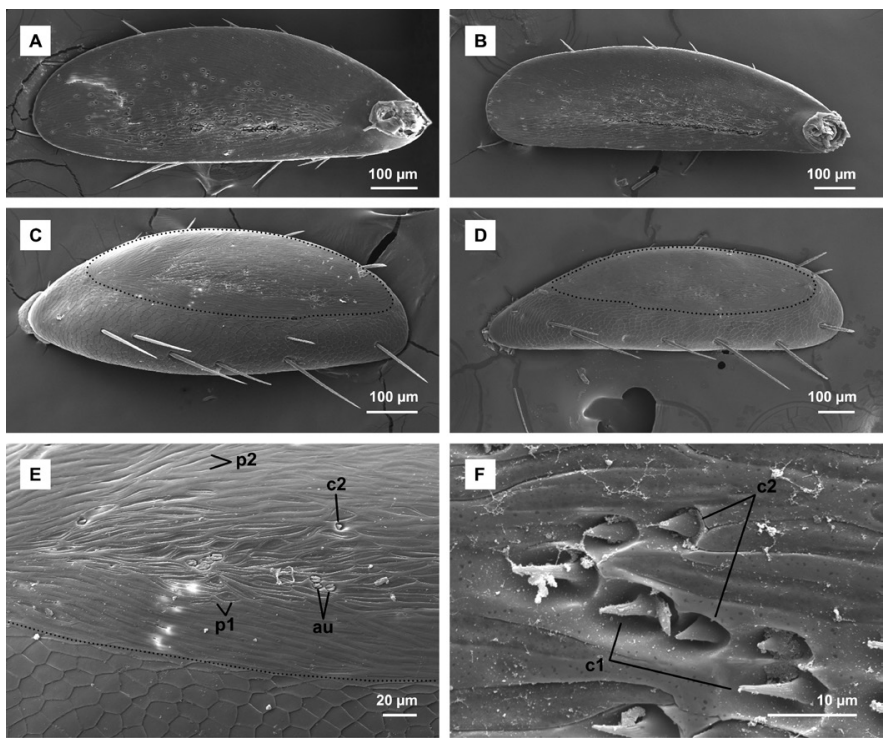

Figure 3 Distal lamella of Liogenys suturalis. A-B) Inner (proximal) side, female (rigth) and male (left). C-D) Outer (distal) side, female (rigth) and male (left). E) Outer side, surface detail, female. F) Inner side, sensilla detail, male. Black dotted line showing posterior area (ventral area when antennae distended) with sensilla placodea, s. coeloconica, and s. auricilica; otherwise the anterior area (dorsal area when antennae distended) has a reticulated surface with some s. trichodea. au, sensilla auricilica; $\mathbf{c 1}$ s. coeloconica I; c2, s. coeloconica II; p1, s. placodea I; p2, s. placodea II.

Table 1

Average of antennal sensilla of Liogenys suturalis.

\begin{tabular}{|c|c|c|c|c|c|c|c|}
\hline \multirow{2}{*}{ Sensilla } & \multicolumn{2}{|c|}{ proximal lamella } & \multicolumn{2}{|c|}{ medial lamella } & \multicolumn{2}{|c|}{ distal lamella } & \multirow{2}{*}{ Total } \\
\hline & outer & inner & outer & inner & outer & Inner & \\
\hline \multicolumn{8}{|l|}{ Females } \\
\hline Placodea & - & 702 & 619 & 853 & 728 & 769 & 3671 \\
\hline Coeloconica & - & 151 & 78 & 71 & 13 & 109 & 422 \\
\hline Auricilica & - & 73 & 72 & 66 & 12 & 83 & 306 \\
\hline Total & - & 926 & 769 & 990 & 753 & 961 & 4399 \\
\hline \multicolumn{8}{|l|}{ Males } \\
\hline Placodea & - & 832 & 727 & 675 & 258 & 625 & 3117 \\
\hline Coeloconica & - & 103 & 63 & 67 & 7 & 113 & 353 \\
\hline Auricilica & - & 196 & 103 & 115 & - & 155 & 569 \\
\hline Total & - & 1131 & 893 & 857 & 265 & 893 & 4039 \\
\hline
\end{tabular}

It is known that melolonthine beetles are attracted both by sexual pheromones and plant volatiles (e.g., Ruther et al., 2000 to Melolontha hippocastani Fabricius, 1801, Melolonthini).

Ochieng et al. (2002) studied the neural response of the antennal sensilla in Phyllophaga anxia (Le Conte, 1850) (Melolonthini) and found evidence to identify s. coeloconica and small s. auricilica (Bohacz et al., 2020: sensilla SA; different from the leaf-shaped sensilla present in Liogenys, Bohacz et al., 2020: sensilla LSS) as olfactory receptors, but could not attributed specific roles to each sensilla type.

Copulation behavior studies in Liogenys suturalis (Ferreira et al., 2018), L. fusca (Rodrigues et al., 2017), and L. bidenticeps (Rodrigues et al., 2017) demonstrated that females could select males for copulation probably using chemical recognition.

The s. placodea in lamellae of Popillia japonica Newman, 1841 (Rutelinae; Bohacz et al., 2020: sensilla G, sensilla as wide as long or almost so and with a cuticular swellings) were associated with pheromone detection (Kim and Leal, 2000), but the s. placodea of this ruteline beetle are quite different from the long and smooth s. placodea of $L$. suturalis (Melolonthinae, Diplotaxini), and it is not clear if the role of these sensilla are the same between both species, despite the morphological variation.

The long and thin sensilla placodea found in L. suturalis are similar to those found in other melolonthine as Maladera orientalis Motschulsky, 1857 (Sericini; Shao et al., 2019), but are slightly different from those found in other melolonthine as in Macrodactylus mexicanus Burmeister, 1855 and M. nigripes Burmeister, 1887 (Macrodactylini; Martínez-Bonilla et al., 2015; Romero-López et al., 2017). The s. placodea of Macrodactylus is wider and have a more concave surface than in L. suturalis.

Other melolonthine that have the elongated s. placodea (as Liogenys) are (Bohacz et al., 2020): Camenta innocua (Boheman, 1857) (Ablaberini), Diphucephala sp (Diphucephalini), Liparetrus obscurus Blanchard, 1846 (Liparetrini), Maladera holosericea (Scopoli, 1772) (Sericini), Phyllotocus navicularis Blanchard, 1850 (Phyllotocini), Triodontella raymondi (Perris, 1870) (Sericini).

Species with known antennal sensilla in melolonthine tribe Melolonthini and Rhizotrogini have different sensilla ornanization from that found in Liogenys. They have several small s. auricilica and rounded s. placodea surrounded by a deep ditch, while Liogenys have long s. placodea with ditch indistinct or shallow and leaf-shaped s. auricilica (Melolonthini: Antitrogus parvulus Britton, 1978 by Allsopp, 1990; Dasylepida ishigakiensis (Niijima and Kinoshita, 1927) by Tanaka et al., 2006; Lepidiota mansueta (Burmeister, 1855) by Handique et al., 2017 and Sreedevi and Kumar, 2018; L. negatoria Blackburn, 1912 by Allsopp, 1990; Melolontha melolontha (Linnaeus, 1758) by Meinecke, 1975; Phyllophaga anxia by Ochieng et al., 2002; P. obsoleta (Blanchard, 1851) by Romero-López et al., 2004; P. ravida (Blanchard, 1851) by RomeroLópez et al., 2010; P. opaca (Moser, 1918) by Romero-López and Morón, 2013; Rhizotrogini: Amphimallon assimile by Bohacz et al., 2020; Am. solstitiale(Linnaeus, 1758) by Meinecke, 1975; Rhizotrogus maculicollis Villa and Villa, 1833 by Meinecke, 1975).

Other melolonthine tribe that have several species with antennal sensilla studied is Hopliini. That tribe has a similar antennal structure like Melolonthini and Rhizotrogini, but some species have s. placodea more folded or forked than in Melolonthini and Rhizotrogini (Hoplia argentea (Poda, 1761) (as H. farinosa) by Meinecke, 1975; Hoplia philanthus (Fuessly, 1775) by Bohacz et al., 2020; and 24 species included in eigth genera by Romero-López et al., 2013).

In respect to sensilla trichodea and s. coeloconica of Liogenys, they are like as in other phytophagous scarab beetles (to a more inclusive comparison see Meinecke, 1975; Zauli et al., 2016; Bohacz et al., 2020).

The arrangement of the leaf-shaped sensilla auricilica on the lamellae of $L$. suturalis, which are mainly grouped in a longitudinal groove in 
the anterior third of the lamellae, has not yet been described in the antennae of Scarabaeidae.

The number of sensilla present in the antennae of $L$. suturalis was 4399 in females and 4039 in males. However, some Scarabaeidae species present higher differences in the amounts of sensilla between males and females. A total of 7428 and 1560 sensilla were quantified in the antennae of males and females of Dasylepida ishigakiensis (Tanaka et al., 2006) respectively, while 7784 sensilla were quantified in females and 5741 in males of Anomala inconstans Burmeister, 1844 (Rodrigues et al., 2019; Rutelinae).

The antennal sensilla to a Liogenys species and to a Diplotaxini taxon are herein described for the first time and the types of sensilla are the same in both sexes.

\section{Acknowledgements}

To the National Institute of Science and Technology (INCT) of Semiochemicals in Agriculture (Fapesp 2014/50871-0 and CNPq 465511/2014-7) for financial support. Juares Fuhrmann thanks Sônia A. Casari (Museum of Zoology, University of São Paulo) for the supervision.

\section{Conflicts of interest}

The authors declare no conflicts of interest.

\section{Author contribution statement}

FTM performed the collections in the field and performed the photos in scanning electron microscopy. FTM, SRR and JF performed the analyzes and interpretations of the data. FTM, SRR and JF contributed to the critical review and addition of intellectual content. FTM, SRR and JF made the corrections and final writing.

\section{References}

Allsopp, P. G., 1990. Sexual dimorphism in the adult antennae of Antitrogus parvulus Britton and lepidiota negatoria Blackburn (Coleoptera: Scarabaeidae: Melolonthinae). J. Aust. Entomol. Soc. 29, 261-266. https://doi.org/10.1111/j.1440-6055.1990.tb00360.x.

Ávila, C. J., Vivan, L. M., Santos, V., 2014. Controle do Coró Liogenys fusca (Blanchard) (Coleoptera: Melolontidae) com inseticidas aplicados nas sementes e no sulco de semeadura da soja (Glycine max). -. BioAssay 9, 1-7.

Bohacz, C., Harrison, J. G., Ahrens, D., 2020. Comparative morphology of antennal surface structures in pleurostict scarab beetles (Coleoptera). Zoomorph. 139, 327-346. https://doi.org/10.1007/ s00435-020-00495-0.

Cherman, M. A., Guedes, J. C., Morón, M. A., Prá, E., Perini, C. R., Jung, A. H., 2011. First record of species of Liogenys (Coleoptera, Melolonthidae) associated with winter grain crops in Rio Grande do Sul (Brazil). Rev. Bras. Entomol. 55, 618-620. https://doi.org/10.1590/S008556262011005000052.

Cherman, M. A., Basílio, D. S., Mise, K. M., Almeira, L. M., 2019. Unraveling the puzzle of Liogenys biodiversity: fifteen new species, nomenclatural acts and new geographical records (Coleoptera: Scarabaeidae). Insect Syst. Evol. 50, 1-69. https://doi.org/10.1163/1876312X-00001040.

Cherman, M. A., Basílio, D. S., Mise, K. M., Frisch, J., Smith, A. B. T., Almeira, L. M., 2020. Liogenys Guérin-Méneville, 1831 (Coleoptera: Scarabaeidae: Melolonthinae) from the southern South American Transition Zone and boundaries: taxonomic overview with four new species. Zootaxa 4896, 46-84. https://doi.org/10.11646/ zootaxa.4896.1.2.

Cherman, M. A., Basílio, D. S., Mise, K. M., Frisch, J., Almeira, L. M., 2021. Liogenys Guérin-Méneville, 1831 (Coleoptera: Scarabaeidae: Melolonthinae: Diplotaxini) from the Chacoan Province and its boundaries: taxonomic overview with four new species. Zootaxa 4938, 1-59. https://doi.org/10.11646/zootaxa.4938.1.1.

Coutinho, G. V., Rodrigues, S. R., Cruz, E. D., Abot, A. R., 2011. Bionomic data and larval density of Scarabaeidae (Pleurosticti) in sugarcane in the central region of Mato Grosso do Sul, Brazil. Rev. Bras. Entomol. 55, 389-395. https://doi.org/10.1590/S0085-56262011005000038.

Ferreira, K. R., Gomes, E. S., Rodrigues, S. R., 2018. Description of the third instar and mating behavior of Liogenys sutiralis (Blanchard) (Coleoptera: scarabaeidae). Coleopt. Bull. 72, 457-464. https://doi. org/10.1649/0010-065X-72.3.457.

Handique, G., Bhattacharyya, B., Baruah, A. A. L. H., Boruah, R., 2017. Antenna morphology and sensilla microstructure of the male and female scarab beetle, Lepidiota mansueta Burmeister (Coleoptera: scarabaeidae). -. Invertebr. Reprod. Dev. 61, 200-205. https://doi org/10.1080/07924259.2017.1287784.

Keil, T. A. 1999. Morphology and development of the peripheral olfactory organs. In: Hansson, B. (ed). Insect Olfaction. Springer, Berlin, pp. 6-44.

Kim, J. Y., Leal, W. S., 2000. Ultrastructure of pheromone-detecting sensillum placodeum of the Japanese beetle, Popillia japonica Newmann (Coleoptera: scarabaeidae). Arthropod Struct. Dev. 29, 121-128. https://doi.org/10.1016/S1467-8039(00)00022-0.

Leal, W. S., Mochizuki, F., 1993. Sex pheromone reception in the scarab beetle Anomala cuprea: enantiomeric discrimination by sensilla placodea. Naturwissenschaften 80,278-281. https://doi.org/10.1007/ BF01135914.

Leal, W. S., 1995. Sex pheromones of plant-feeding scarab beetles. Korean J. Appl. Entomol. 34, 9-14.

Leal, W. S., 1998. Chemical ecology of phytophagous scarab beetles. Annu. Rev. Entomol. 43, 39-61. https://doi.org/10.1146/annurev. ento.43.1.39.

Li, X., Ju, Q., Jie, W., Li, F., Jiang, X., Hu, J., 2015. Chemosensory gene families in adultantennae of Anomala corpulenta Motschulsky (Coleoptera: Scarabaeidae: Rutelinae). PLoS One 10, 1-22. https:// doi.org/10.1371/journal.pone.0121504.

Maia, A. C. D., Schlindwein, C., 2006. Caladium bicolor (Araceae) and Cyclocephala celata (Coleoptera, Dynastinae): a well-established pollination system in the northern Atlantic rainforest of Pernambuco, Brazil. Plant Biol. 8, 529-534. https://doi.org/10.1055/s-2006-924045.

Maia, A. C. D., Gibernau, M., Carvalho, A. T., Gonçalves, E. G., Schlindwein, C., 2013. The cowl does not make the monk: scarab beetle pollination of the Neotropical aroid Taccarum ulei (Araceae: Spathicarpeae). Biol. J. Linn. Soc. Lond. 108, 22-34. https://doi.org/10.1111/j.10958312.2012.01985.x.

Martínez, L. C., Plata-Rueda, A., Zanuncio, J. C., Serrão, J. E., 2013. Leucothyreus femoratus (Coleoptera, Scarabaeidae): feeding and behavioral activities as an oil palm defoliator. Fla. Entomol. 96, 55-63. https://doi.org/10.1653/024.096.0107.

Martínez-Bonilla, O. K., Romero-López, A. A., Benítez-Herrera, L. N. 2015. Morfometría corporal y antenal Macrodactylus mexicanus y Macrodactylus nigripes (Coleoptera: Scarabaeoidea: Melolonthidae) y descripción de sus sensilas lamelares. Bol. Soc. Mex. Entomol. (sp 1), 81-87.

Meinecke, C. C., 1975. Riechsensillen und systematik der Lamellicornia (Insecta: coleoptera). Zoomorphologie 82, 1-42. https://doi. org/10.1007/BF00995905. 
Ochieng, S. A., Robbins, P. S., Roelofs, W. L., Baker, T. C., 2002. Sex pheromone reception in the scarab beetle Phyllophaga anxia (Coleoptera: scarabaeidae). Ann. Entomol. Soc. Am. 95, 97-102. https://doi.org/10.1603/0013-8746(2002)095[0097:SPRITS]2.0.CO;2.

Rodrigues, S. R., Barbosa, C. L., Puker, A., Abot, A. R., Ide, S., 2008. Occurrence, biology and behavior of Liogenys fuscus Blanchard (Insecta, Coleoptera, Scarabaeidae) in Aquidauana, Mato Grosso do Sul, Brazil. Rev. Bras. Entomol. 52, 637-640. https://doi.org/10.1590/ S0085-56262008000400015.

Rodrigues, S. R., Carmo, J. I., Oliveira, V. S., Tiago, E. F., Taira, T. L., 2011. Ocorrência de larvas de Scarabaeidae fitófagos (Insecta: Coleoptera) em diferentes sistemas de sucessão de culturas. Pesqui. Agropecu. Trop. 41, 87-93. https://doi.org/10.5216/pat.v41i1.7698.

Rodrigues, S. R., Gomes, E. S., Bento, J. M. S., 2014b. Sexual dimorphism and mating behavior in Anomala testaceipennis. J. Insect Sci. 14, 210-210. https://doi.org/10.1093/jisesa/ieu072.

Rodrigues, S. R., Nogueira, G. A. L., Gomes, E. S., 2014a. Biological aspects of Liogenys bidenticeps Moser, 1919 (Coleoptera: scarabaeidae). Coleopt. Bull. 68, 235-238. https://doi.org/10.1649/0010-065X-68.2.235.

Rodrigues, S. R., Fuhrmann, J., Amaro, R. A., 2019. Aspects of mating behavior and antennal sensilla in Anomala inconstans Burmeister, 1844 (Coleoptera: Scarabaeidae: Rutelinae). Biota Neotrop. 19, 1-7. https://doi.org/10.1590/1676-0611-bn-2018-0664.

Rodrigues, S. R., Fuhrmann, J., Gomes, E. S., Amaro, R. A., 2017. Description of immatures and mating behavior of Liogenys bidenticeps Moser, 1919 (Coleoptera: Melolonthidae: Melolonthinae). Rev. Bras. Entomol. 61, 339-348. https://doi.org/10.1016/j.rbe.2017.07.006.

Romero-López, A. A., Arzuffi, R., Valdez, J., Morón, M. A., CastrejónGómez, V., Villalobos, F. F., 2004. Sensory organs in the antennae of Phyllophaga obsoleta (Coleoptera: melolonthidae). Ann. Entomol. Soc. Am. 97, 1306-1312. https://doi.org/10.1603/00138746(2004)097[1306:SOITAO]2.0.CO;2.

Romero-López, A. A., Morón, M. A., Valdez, J., 2010. Sexual dimorphism in antennal receptors of Phyllophaga ravida Blanchard (Coleoptera: Scarabaeoidea: Melolonthidae). Neotrop. Entomol. 39, 957-966. https://doi.org/10.1590/S1519-566X2010000600018.

Romero-López, A. A., Carrillo-Ruiz, H., Morón, M. A., 2013. Morphological diversity of antennal sensilla in Hopliinae (Coleoptera: Scarabaeoidea: Melolonthidae). Acad.J. Entomol. 6, 20-26. https://doi.org/10.5829/ idosi.aje.2013.6.1.73187.
Romero-López, A. A., Morón, M. A., 2013. Chapter 2. Sexual dimorphism in antennae of Mexican species of Phyllophaga. In: Moryiama, H. Sexual dimorphism. InTech books, Rijeka, pp 17-34.

Romero-López, A. A., Benítez-Herrera, L. M., Martínez-Bonilla, O. K., Yanes-Gómez, G., Aragón-Sánchez, M., 2017. Comparative study of distribution of antennal chemoreceptors of Macrodactylus of Mexico. Southwest. Entomol.42, 111-119. https://doi.org/10.3958/059.042.0110.

Ruther, J., Reinecke, K., Tolasch, T., Francke, W., Hilker, M., 2000. Mate finding in the forest cockchafer, Melolontha hippocastani, mediated by volatiles from plants and females. Physiol. Entomol. 25, 172-179. https://doi.org/10.1046/j.1365-3032.2000.00183.x.

Santos, A. C., Bueno, A. F., Bueno, R. C. O. F., Vieira, S. S., 2008. Chemical control of white grub Liogenys fuscus (Blanchard 1851) (Coleoptera: Melolonthidae) in cornfields. BioAssay 3, 1-6.

Santos, V., Ávila, C. J., 2007. Coró-do-milho Liogenys suturalis. Embrapa Agropecuária Oeste, Dourados.

Santos, V., Ávila, C. J., 2009. Aspectos biológicos e comportamentais de Liogenys suturalis Blanchard (Coleoptera: Melolontidae) no Mato Grosso do Sul. Neotrop. Entomol. 38, 734-740. https://doi. org/10.1590/S1519-566X2009000600005.

Schneider, D., 1964. Insect antennae. Annu. Rev. Entomol. 9, 103-122. https://doi.org/10.1146/annurev.en.09.010164.000535.

Shao, K., Sun, Y., Wang, W., Chen, L., 2019. A SEM study of antennal sensilla in Maladera orientalis Motschulsky (Coleoptera: Scarabaeidae: Melolonthinae). Micron 119, 17-23. https://doi.org/10.1016/j. micron.2019.01.004.

Silveira Neto, S., Silveira, A. C., 1969. Armadilha luminosa modelo "Luiz de Queiroz". Solo 61, 19-21.

Sreedevi, K., Kumar, P. V., 2018. Sexual dimorphism in antennal sensilla of Lepidiota mansueta (Burmeister) (Coleoptera: Scarabaeidae: Melolonthinae). J. Appl. Zool. Res. 29, 23-29.

Tanaka, S., Yukuhiro, F., Wakamura, S., 2006. Sexual dimorphism in body dimensions and antennal sensilla in the white grub beetle, Dasylepida ishigakiensis (Coleoptera, Scarabaeidae). Appl. Entomol. Zool. 41, 455-461. https://doi.org/10.1303/aez.2006.455.

Zauli, A., Maurizi, E., Carpaneto, G. M., Chiari, S., Svensson, G. P., Giulio, A., 2016. Antennal fine morphology of the threatened beetle Osmoderma eremita (Coleoptera: Scarabaeidae), revealed by scanning electron microscopy. Microsc. Res. Tech. 79, 178-191. https://doi.org/10.1002/jemt.22618. 